\title{
International Women's Day Through the Perspective of Sustainable Development Goals
}

\section{Salma Rattani*}

Assistant Professor, Aga Khan University, School of Nursing, Karachi, Pakistan

*Corresponding Author: Salma Rattani, Assistant Professor, Aga Khan University, School of Nursing, Karachi, Pakistan.
Received: February 29,2020

Published: March 20, 2020

(C) All rights are reserved by Salma Rattani.
In 1911 celebrated first on March 19, and now on March 8, the international women's day is inspired by American's National Women Day on February 28, 1909, declared by the Socialist Party of America. The first International Women's Day was supported through rally by a million women and men in support of women's rights in all the spheres of their lives. These include socio-cultural, physical, psychological, and emotional dimensions and extending to women's geopolitical rights in the society [1]. Each year the day is marked around a theme which for this year is '\#Each for Equal'. The United Nations advocate that men and women are equal and therefore, it is included in the Sustainable Development Goals (SDGs). Among the 17 SDGs, Goal 5 is 'achieve gender equality and empower all women and girls'. This goal aims not to discriminate among men and women but to provide them equal rights. This is the moral and ethical responsibility of the society that girls' and women's equal rights be accepted, respected and permitted. These are to be translated through policies and actions by those in authorities which starts from the family projected through their emotions at the time of the birth of a girl and a boy [2].

In SDG 5 there are six targets focusing to protect women and girls. These are to protect them from discrimination, violence, and harmful practices. Value their unpaid care and domestic work through sharing their household responsibilities and providing them social protection. Accept women's leadership capabilities and recognize these by providing women with equal opportunities. Provide girls and women with universal access to sexual and reproductive health [3]. These targets are to be translated into the actions until then SDG 5 five cannot be achieved. Informing about a ground reality Dr. Flavia Bustreo, Assistant Director-General World Health Organization states that in too many countries women empowerment remains pipedream- little more than a rhetorical flourish added to a politician's speech [4]. What Dr. Bustreo describes is quite true in low-and-middle-income countries (LMICs) and I say this based on my personal experience of living in an LMIC. In these countries, girls and women face discrimination even by their family members. Women are considered inferior to their male members in the family. The same holds for all the targets of the goal 5 mentioned earlier. All the six targets set under this goal must be advocated during different forums planned to be organized in celebration of International Women's Day 2020.

\section{Bibliography}

1. Lewis JJ. "A Brief History of International Women's Day" (2020).

2. United Nations. "Sustainable Development Goals. Goal 5: Achieve gender equality and empower all women and girls".

3. Horton R. "Offline: Gender equality-the neglected SDG for health". The Lancet 386.10007 (2015): 1928.

4. Bustreo F. "Promoting health through the life-course". Ten top issues for women's health. World Health Organization (2016).

\section{Assets from publication with us}

- Prompt Acknowledgement after receiving the article

- Thorough Double blinded peer review

- Rapid Publication

- Issue of Publication Certificate

- High visibility of your Published work

Website: www.actascientific.com/

Submit Article: www.actascientific.com/submission.php

Email us: editor@actascientific.com

Contact us: +919182824667 